\title{
EVALUATION OF EARLY ISCHEMIC CHANGES IN STROKE PATIENTS TREATED WITH THROMBOLYTIC THERAPY
}

\author{
Kolevski Goran, ${ }^{1}$ Korneti-Pekevska Kostandina ${ }^{2}$ \\ ${ }^{1}$ Clinic of Neurology, Clinical center Skopje, R. Macedonia \\ ${ }^{2}$ Institute of Anatomy, Medical Faculty University "Sts Cyril and Methodius", Skopje, R. Macedonia \\ Primljen/Received 04. 05. 2016. god. \\ Prihvaćen/Accepted 28. 06. 2016. god.
}

Abstract: Introduction: The aim of this study is to evaluate early brain ischemic changes on CT scan in stroke patients in correlation with the clinical outcome, as well as to evaluate if there is prognostic and predictive features that can be used. Patients and methods: We examined 20 patients with acute ischemic stroke, from which 12 were male and 8 were female, at the age from 47 to 76 years. Results: The hyperdense medial artery (HMA) sign was present in $10(50 \%)$ patients. Concerning the ASPECTS score, 5 patients (25\%) had normal score of 10 points, while 7 patients $(35 \%)$ had score of 7 points. 12 patients $(60 \%)$ had unfavorable outcome, while 8 patients (40\%) had favorable outcome. Our statistical analysis shows that age of more than 65 years, presence of 2 or more risk-factors, ASPECTS score of 7 and presence of HMA sign were all statistically significant predictors of unfavorable outcome in examined patients $(p<0.05$ each). The presence of the hyperdense medial artery sign was the most significant single predictor for unfavorable clinical outcome $(\mathrm{p}=$ $0.0042, p<0.05$ ). Conclusion: The presence of HMA sign is the most significant single predictor for unfavorable clinical outcome.

Key words: stroke; hyperdense medial artery sign; outcome; thrombolysis.

\section{INTRODUCTION}

Acute ischemic stroke is characterized by the sudden loss of blood circulation to an area of the brain, resulting in a corresponding loss of neurologic function. Acute ischemic stroke is caused by thrombotic or embolic occlusion of a cerebral artery. This is a clinical emergency that requires prompt diagnosis and treatment (1).

Acute ischemic stroke is one of the most important causes of death and long-term disability in the world. According to the World Health Organization (WHO), 15 million people suffer from stroke worldwide each year (2). Of these, 5 million die, and around 5 million are permanently disabled. Acute ischemic stroke constitutes approximately $85 \%$ of all strokes. Contemporary and comprehensive management of ischemic stroke require prompt access to neuroimaging and thrombolytic therapy.

Neuroimaging plays a very significant role in the evaluation of patients suspected of acute ischemic stroke. Computed tomography (CT) is the first line diagnostic test for the emergency evaluation of acute stroke due to accuracy of imaging, widespread availability and its low cost (3).

There are subtle changes on non-contrast $\mathrm{CT}$ that can be used for prompt diagnosis of acute ischemic stroke. Those changes are hypoatenuation of areas in brain parenchyma, cortical swelling with sulcal effacement, loss of gray-white matter differentiation, as well as hyperdense medial cerebral artery sign (4).

Alberta Stroke Program Early CT score (ASPECTS) is a clinical tool that uses non-contrast CT for evaluation of early ischemic brain changes. This is a 10-point medial artery zone quantitative topographic CT scan score $(5,6)$. ASPECTS offers the reliability and utility of a standard CT examination with a reproducible grading system to assess early ischemic changes on pretreatment CT studies in patients with acute ischemic stroke of the anterior circulation. To compute the ASPECTS, 1 point is subtracted from 10 for any evidence of early ischemic change for each of the predefined brain regions. ASPECTS score of 10 means that there are no early ischemic changes. This score is widely recognized and used in many studies $(7,8,9)$.

Another tool for evaluation of early brain ischemic changes is the hyperdense medial artery (HMA) sign (Figure 1) (10). It has been known to be an indica- 


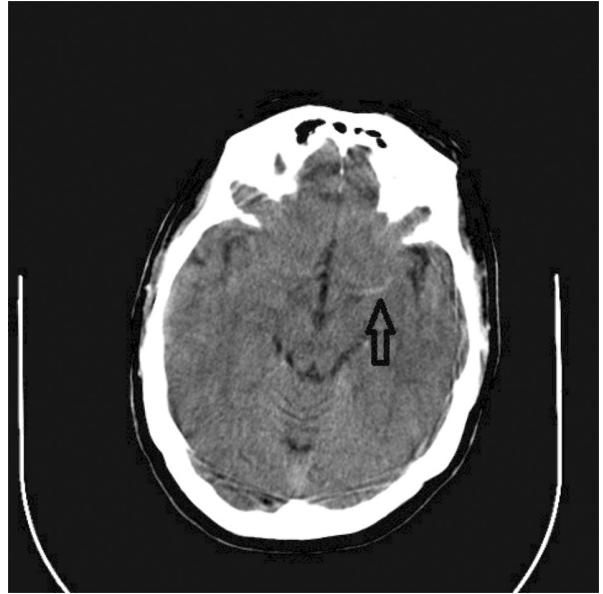

Figure 1. Hyperdense media artery (HMA) sign

tor of occluding clot in cases of acute ischemia on non-enhanced CT, for a long time. Additionally, it is the earliest sign, and is visible long before early parenchymal changes. HMA sign becomes visible within the onset of occlusion in a medial cerebral artery M1-segment. The histopathological analogue for the HMA sign is a thrombus occluding the vessel.

Evidence from a numerous studies suggest that early ischemic changes on non-contrast CT before the administration of intravenous thrombolysis can predict functional outcome of patients (11).

Intravenous thrombolysis with recombinant tissue plasminogen activator (rt-PA) has been widely accepted and used as a safe and effective treatment in patients whose onset of symptoms is within $4.5 \mathrm{~h}$. Nowadays, diagnostic imaging technologies play an important role in determining which patient will have the greater benefit from administering the thrombolytic medication $(12,13)$.

The aim of our study was to evaluate these changes in correlation to clinical outcome of patients, as well as to evaluate if there is a prognostic and predictive features that can be used.

\section{PATIENTS AND METHODS}

In this study, we examined 20 patients with acute ischemic stroke, treated at the Clinic of neurology-Skopje, Macedonia, in the period from June to November 2015. Non-contrast CT was used to detect early ischemic changes and to exclude intracerebral hemorrhage. All patients fulfilled criteria for thrombolytic treatment and received appropriate intravenous thrombolytic therapy recombinant tissue plasminogen activator (Actilyse / rt-PA, Boehringer Ingelheim, Germany). This therapy was given using standard protocol $(0.9 \mathrm{ml} / \mathrm{kg} ; 10 \%$ in bolus, $90 \%$ in 1 hour infusion). The outcome was measured using the modified Rankin Scale (mRS) which is commonly used for measuring the degree of disability or dependence in patient with stroke (14). A 3-month follow-up status was measured by the $\mathrm{mRS}$ and then dichotomized into either favorable $(\mathrm{mRS} \leq 2)$ or unfavorable (mRS $>2)$ outcome groups.

Non-contrast CT findings indicating early ischemic changes for each patients were analyzed with ASPECTS grading system as well as HMA sign.

Age and presence of risk factors (hypertension, hyperlipidemia, previous stroke or TIA, previous myocardial infarction, diabetes, smoking) as variables that can influence the outcome were also evaluated.

Standard statistical methods for descriptive statistic were used, as well as determination of correlation between examined data groups. Also, logistic regression analysis was used in order to evaluate the probability to determine the outcome. P values of $<0.05$ were considered as statistically significant.

\section{RESULTS}

We examined 20 patients with acute ischemic stroke, from which 12 were male and 8 were female, at the age from 47 to 76 years (mean age $61 \pm 11$ SD). 12 patients $(60 \%)$ were older than 65 years. Presence of these risk-factors were evaluated: hypertension, hyperlipidemia, previous stroke or TIA, previous myocardial infarction, diabetes and smoking. The most present risk-factor was hypertension $(12 / 60 \%)$, followed by hyperlipidemia and smoking $(8 / 40 \%$ each). Also, from the total of 20 patients, 12 patients $(60 \%)$ had 2 or more risk-factors.

The hyperdense medial artery (HMA) sign was present in $10(50 \%)$ patients.

Concerning the ASPECTS score, 5 patients $(25 \%)$ had normal score of 10 points, while 7 patients (35\%) had score of 7 points. There were no patients with ASPECTS score lower than 7. According to guidelines for thrombolytic therapy, it is contraindicated to give this therapy when there are early ischemic changes over one-third of brain hemisphere (ASPECTS score $<7$ ).

The outcome was measured using the mRS, at $3^{\text {rd }}$ month after the ischemic stroke, and results where dichotomized into either favorable $(\mathrm{mRS} \leq 2)$ or unfavorable (mRS $>2)$ outcome groups. 12 patients $(60 \%)$ had unfavorable ( $\mathrm{mRS}>2)$ outcome, while 8 patients $(40 \%)$ had favorable $(\mathrm{mRS} \leq 2)$ outcome.

There was statistically significant correlation between age (especially age of more than 65 years) and presence of risk-factors (especially presence of 2 or more risk-factors), in relation to the outcome ( $p<0.05$ both). Also, there was statistically significant correlation between ASPECTS score values and the outcome $(\mathrm{p}<0.05)$. We use Fisher's exact test when we analyzed the presence of HMA sign in relation to outcome. 
Results confirmed that there is a statistically significant relationship between presence of hyperdense medial artery (HMA) sign and unfavorable outcome.

We also describe the relationship between the outcome, presented as dependent dichotomous variable of $\mathrm{mRS}$ [favorable $(\mathrm{mRS} \leq 2)$ or unfavorable $(\mathrm{mRS}>2)$ outcome] on one side, and measured independent variables (age, presence of risk factors, ASPECTS and HMA sign) on other side. For this purpose we used the logistic regression analysis. This statistical analysis shows that age of more than 65 years, presence of 2 or more risk-factors, ASPECTS score of 7 and presence of HMA sign were all statistically significant predictors of unfavorable outcome in examined patients $(\mathrm{p}<$ 0.05 each). Also, ASPECTS score of more than 7 points was found not to be significant prediction factor for favorable outcome $(p=0.42)$. The presence of the hyperdense medial artery (HMA) sign was the most significant single predictor for unfavorable clinical outcome $(\mathrm{p}=0.0042, \mathrm{p}<0,05)($ Table 1$)$.

Table 1. Clinical variables of patients with favourable or unfavourable functional outcomes

\begin{tabular}{|l|c|c|}
\hline Clinical variables & $\begin{array}{c}\text { mRS } \leq 2 \\
\text { favourable } \\
\text { outcome } \\
\text { (n.of patients) }\end{array}$ & $\begin{array}{c}\text { mRS }>2 \\
\text { unfavourable } \\
\text { outcome } \\
\text { (n. of patients) }\end{array}$ \\
\hline Age $>65 \mathrm{y}$. & 2 & 10 \\
Age $\leq 65 \mathrm{y}$. & 6 & 2 \\
\hline Risk-factors $\geq 2$ & 2 & 10 \\
Risk-factors $<2$ & 6 & 2 \\
\hline ASPECTS 7 & 1 & 6 \\
ASPECTS $>7$ & 7 & 6 \\
\hline HMA sign present & 1 & 9 \\
HMA sign absent & 7 & 3 \\
\hline
\end{tabular}

ASPECTS - Alberta Stroke Program Early CT Score; HMA sign - Hyperdense Medial Artery sign; mRS - modified Rankin Scale

\section{DISCUSSION}

Early brain ischemic changes can be evaluated using the non-contrast CT. This is of great importance, because it allows to get early diagnostic data of patients in acute phase of stroke. After that, appropriate therapeutic measures can be used. ASPECTS score and HMA signs are widely used CT parameters in neuroimaging. Their clinical significance is confirmed in many studies.

Prediction of outcome as guideline for further treatment is needed for all patients who are suspected of acute ischemic stroke, because treatment decision is made in the acute stage when the final diagnosis is still unclear $(15,16)$.

Our results confirmed that there is a good correlation between age, presence of risk-factors, and also ASPECTS score points and presence of HMA sign (17).

We have selected prediction factors that are widely available to the neurologists in the acute stage, that are very helpful in managing patients with stroke (18). Concerning the possibility of predicting the outcome, our results showed that presence of HMA sign can be used for this purpose. In our study, we confirmed that presence of the hyperdense medial artery (HMA) sign is the most significant single predictor for unfavorable clinical outcome. Also, age of more than 65 years, presence of 2 or more risk-factors and ASPECTS score of 7 can be used as predictors of unfavorable outcome in patients with acute stroke. In his work, Milosavljevic and Ivkovic examined the role of CT brain perfusion in cases of acute brain stroke following thrombolytic therapy, in which they successfully saved ischeamic penumbra in their patients. This will be our goal for future work in the field of acute stroke therapy. Our results are in concordance with several other studies $(19,20,21,22)$.

\section{CONCLUSION}

We can conclude that age of more than 65 years, presence of 2 or more risk-factors, ASPECTS score of 7 and presence of HMA sign are all statistically significant predictors of unfavorable outcome in examined patients. The presence of HMA sign is the most significant single predictor for unfavorable clinical outcome. Those prediction factors can be used for further planning appropriate measures, in order to achieve the best possible therapeutic solutions for patients with acute ischemic stroke.

\section{Conflict of interest}

The autors declare that there are no conflicts of interest.

\section{Abbreviations}

WHO - World Health Organization

CT - Computed tomography

ASPECTS - Alberta Stroke Program Early CT score

HMA - hyperdense cerebral media artery

mRS - modified Rankin Scale 


\title{
Sažetak
}

\section{EVALUACIJA RANIH ISHEMIJSKIH PROMENA KOD PACIJENATA SA MOŽDANIM UDAROM TRETIRANIH TROMBOLITIČKOM TERAPIJOM}

\author{
Kolevski Goran, ${ }^{1}$ Korneti-Pekevska Kostandina ${ }^{2}$ \\ ${ }^{1}$ Clinic of Neurology, Clinical center Skopje, R. Macedonia \\ ${ }^{2}$ Institute of Anatomy, Medical Faculty University "Sts Cyril and Methodius”, Skopje, R. Macedonia
}

Uvod: Cilj ove studije je evaluacija ranih ishemičnih promena mozga upotrebom kompjuterizovane tomografije, kod pacijenata sa akutnim moždanim udarom, u korelaciji sa kliničkim ishodom, kao i procena pojedinih prognostičkih parametara. Pacijenti i metode: Ispitali smo 20 pacijenata sa akutnim ishemijskim moždanim udarom, od kojih 12 muškog, a 8 ženskog pola, starosti od 47 do 76 godina. Rezultati: Hiperdenzni znak medijalne cerebralne arterije je bio prisutan kod $10(50 \%)$ pacijenata. U odnosu na ASPECTS skor, 5 pacijenata $(25 \%)$ su imali normalan skor od 10 poena, dok je 7 pacijenata (35\%) imalo skor od 7 poena. 12 pacijenata $(60 \%)$ je imalo nepovoljan ishod, dok je 8 pacijenata (40\%) imalo povoljan ishod.

\section{REFERENCES}

1. Ropper A H, Brown R H. Adams and Victor's Principles of Neurology. 8th Edition. New York: McGraw-Hill Professional-medical publishing division, USA, 2005.

2. MacKay J, Mensah GA. World Health Organization. Global Burden of Stroke. The Atlas of Heart Disease and Stroke. Available at http://www.who.int/cardiovascular_diseases/en /cvd_atlas_15_burden_stroke.pdf.

3. Wintermark M, Sanelli PC, Albers GW, et al. Imaging recommendations for acute stroke and transient ischemic attack patients: A joint statement by the American Society of Neuroradiology, the American College of Radiology, and the Society of NeuroInterventional Surgery. Am J Neuroradiol. 2013; 34(11): E117-27.

4. von Kummer R, Meyding-Lamadu U, Forsting M, et al. Sensitivity and prognostic value of early $\mathrm{CT}$ in occlusion of the middle cerebral artery trunk. Am J Neuroradiol. 1994; 15(1): 9-15.

5. Barber PA, Demchuk AM, Zhang J, Buchan AM. Validity and reliability of a quantitative computed tomography score in predicting outcome of hyperacute stroke before thrombolytic therapy. ASPECTS Study Group. Alberta Stroke Programme Early CT Score. Lancet. 2000; 355(9216): 1670-4.

6. Dzialowski I, Hill MD, Coutts SB, et al. Extent of early ischemic changes on computed tomography (CT) before thrombolysis: prognostic value of the Alberta Stroke Program Early CT Score in ECASS II. Stroke. 2006; 37(4): 973-8.

7. Mak HK, Yau KK, Khong PL, et al. Hypodensity of $>1 / 3$ middle cerebral artery territory versus Alberta Stroke Programme Early CT Score (ASPECTS): comparison of two methods of quantitative evaluation of early CT changes in hyperacute ischemic stroke in the community setting. Stroke. 2003; 34(5): 1194-6.
Statistička analiza podataka pokazala je da uzrast od preko 65 godina, prisutvo 2 ili više faktora rizika, ASPECTS skor od 7 i prisustvo hiperdenznog znaka medijalne cerebralne arterije su bili statistički signifikantni prediktori za nepovoljan ishod ( $p<0,05$ svaki). Prisustvo hiperdenznog znaka medijalne cerebralne arterije je bio najznačajniji pojedinačni prediktor nepovoljnog ishoda kod ispitivanih pacijenata $(\mathrm{p}=0,0042$; $\mathrm{p}<0,05)$. Zaključak: Prisustvo hiperdenznog znaka medijalne cerebralne arterije jeste najznačajniji prediktor za nepovoljni klinički ishod.

Ključne reči: moždani udar, hiperdenzni znak medijalne cerebralne arterije, ishod, trombolitička terapija.

8. Pexman JH, Barber PA, Hill MD, et al. Use of the Alberta Stroke Program Early CT Score (ASPECTS) for assessing CT scans in patients with acute stroke. Am J Neuroradiol. 2001; 22(8): 1534-42.

9. Weir NU, Pexman JH, Hill MD, Buchan AM, CASES investigators. How well does ASPECTS predict the outcome of acute stroke treated with IV tPA? Neurology. 2006; 67(3): 516-8.

10. Rutgers DR, van der Grond J, Jansen GH, Somford DM, Mali WP. Radiologic-pathologic correlation of the hyperdense middle cerebral artery sign. A case report. Acta Radiol. 2001; 42(5): 467-9.

11. Hacke W, Kaste M, Bluhmki E, et al. Thrombolysis with alteplase 3 to 4.5 hours after acute ischemic stroke. N Engl J Med. 2008; 359(13): 1317-29.

12. The National Institute of Neurological Disorders and Stroke rt-PA Stroke Study Group. Tissue plasminogen activator for acute ischemic stroke. N Engl J Med. 1995; 333(24): 1581-7.

13. Kim JT, Park MS,Nam TS, et al. Thrombolysis as a factor associated with favorable outcomes in patients with unclear-onset stroke. Eur J Neurol. 2011; 18(7): 988-94.

14. Quinn TJ, Dawson J, Walters M. Dr. John Rankin; his life, legacy and the 50th anniversary of the Rankin stroke scale. Scott Med J. 2008; 53(1): 44-7.

15. Brown DL, Johnston KC, Wagner DP, Haley EC Jr. Predicting major neurological improvement with intravenous recombinant tissue plasminogen activator treatment of stroke. Stroke. 2004; 35(1): 147-50.

16. Saposnik G, Di Legge S, Webster F, Hachinski V. Predictors of major neurologic improvement after thrombolysis in acute stroke. Neurology. 2005; 65(8): 1169-74.

17. Heiss WD. The ischemic penumbra: correlates in imaging and implications for treatment of ischemic stroke. Cerebrovasc Dis. 2011; 32(4): 307-20. 
18. Hill MD, Demchuk AM, Tomsick TA, Palesch YY, Broderick JP. Using the baseline CT scan to select acute stroke patients for IV-IA therapy. Am J Neuroradiol. 2006; 27(8): 1612-6.

19. Johnston KC, Connors AF Jr, Wagner DP, Knaus WA, Wang X, Haley EC Jr: A predictive risk model for outcomes of ischemic stroke. Stroke. 2000; 31(2): 448-55.

20. Konig IR, Ziegler A, Bluhmki E, et al. Predicting long-term outcome after acute ischemic stroke: a simple index

\section{Correspondence to / Autor za korespondenciju}

Kolevski Goran, MD, MSc;

Clinic of Neurology, Clinical center Skopje, Macedonia bul. Vodnjanska 18, 1000 Skopje, Macedonia

e-mail: gogomk@hotmail.com;

phone: ++389 75 481025; works in patients from controlled clinical trials. Stroke. 2008; 39(6): 1821-6.

21. Reid JM, Gubitz GJ, Dai D, et al. Predicting functional outcome after stroke by modelling baseline clinical and CT variables. Age Ageing. 2010; 39(3): 360-6.

22. Milosavljević T, Ivković A. Rescuing the ischemic penumbra: Our experience. Sanamed. 2013; 8(2): 123-30. 